\title{
アクティブ歩行器の研究開発
}

\section{Development of Active Walker by using Hart Walker}

小林 宏、○尾形 正明、唐渡 健夫、中山 総、辻 俊明

東京理科大学 工学部 機械工学科

入江 和隆

(合) ハートウォーカージャパン

Hiroshi Kobayashi, Dept. of Mechanical Engineering, Tokyo University of Science Masaaki Ogata, Dept. of Mechanical Engineering, Tokyo University of Science Karato Takeo, Dept. of Mechanical Engineering, Tokyo University of Science Nakayama Sou, Dept. of Mechanical Engineering, Tokyo University of Science Tuji Tosiaki, Dept. of Mechanical Engineering, Tokyo University of Science Irie Kazutaka, Co.Hart Walker Japan

\section{1.はじめに}

歩行障害者の日常生活での歩行を可能にするために, 様々な歩行補助器具方開発されている. 最も用いられる歩行 器は, 前方や後方を両手で握り体幹を保持しながら歩行動 作を実現するものであるが，姿勢が悪くなってしまったり，特 別な施設が必要な物である.

そのため, 本研究ではアクティブ歩行器の開発を行ってい る.これはHart Walker(Fig.1) (以下 HW)という歩行補助 具を用いたもので, 転倒する事がなく, 正しい姿勢が保持で きると共に両手が自由になる. また、McKibben 型人工筋肉 を取り付けることで全く歩けない人でも自律的に歩行動作が できるようになっている. 以下, 開発の概要を示すと共に, 健 常者の歩行パターンの分析と, 子供サイズの人形を用いた歩 行実験を行ったので報告する。

\section{2. アクティブ歩行器の構成}

2.1 アクチュエータアアクティブ歩行器に用いている McKibben 型人工筋は、Fig.2 に示すようにゴムチューブをナ イロン製のコードを網目状に編んだスリーブで覆い、両端を固 定したものである。ゴムチューブに压縮空気を加えると円周方 向に膨張する。円周方向のカはスリーブの網目の角度が変 わり、軸力向への強力な収縮力となる。これを関節間に配置 する事により、収縮力を回転力とし、各動作を実現する。

Fig.3には、アクチュエータの配置を示す。

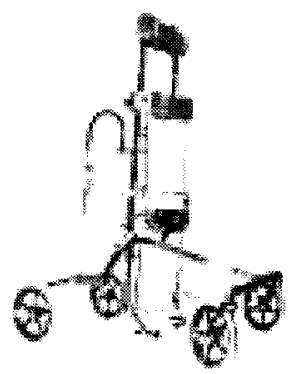

Fig.1 Hart Walker

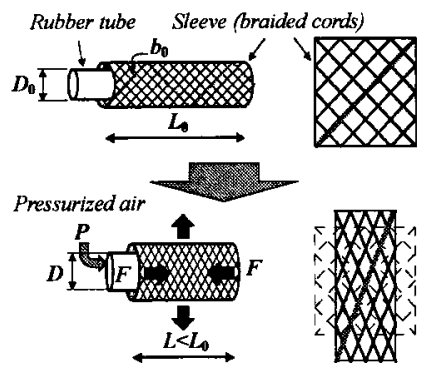

Fig.2 Structure of actuator
2.2 制御方法 McKibben 型人工筋肉の制御は, 空 気圧を制御する必要があるため, 電空レギュレー夕を用 いている。これは，PCから DA ボードを介し，電压を 変化させることにより空圧を制御できる。制御する空気 圧のパターンは経験的に作った。その際，地面との接触
による外力をあらかじめ予測すること，また，他関節の 運動の影響に注意する必要があった。

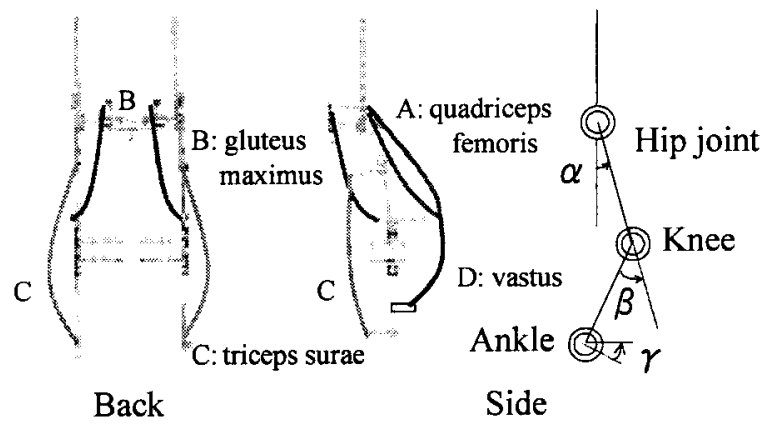

Fig.3 Actuator layout

\section{3. 歩行实医}

アクティブ歩行器に $130 \mathrm{~cm}, 25 \mathrm{~kg}$ の関節を持った人形を 取り付け実験を行った. 歩行パターンは, 健常者を参考とし て作り出した．数人の健常者の歩行時の各関節角度を三次 元測定器で測定し, その中で, 全ての人間が持つ傾向をアク ティブ歩行器にて実現した. 各角度変化のグラフを Fig.4に 示す.

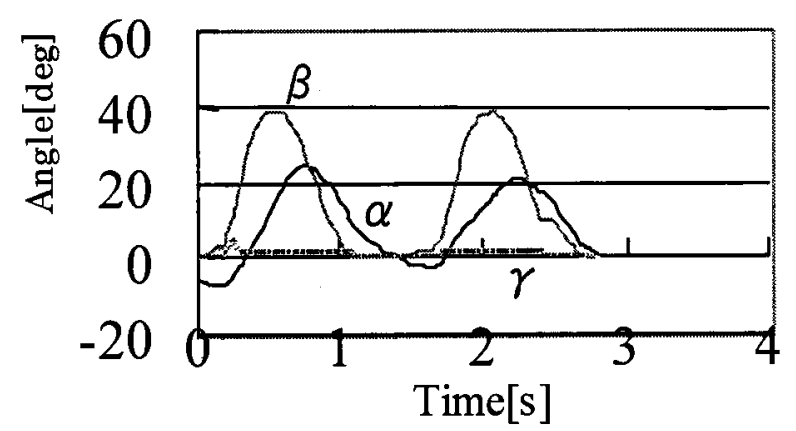

Fig. 4 Realized gait by the active walker

\section{4. 結言}

本研究では人間の子供と同じサイズ, 重さの人形を用い, アクティブ歩行器に取り付けて健常者と同様の歩行を行う事 が出来た.これにより, 全く力の無い人間でも、アクティブ歩 行器を用いて健常者のように歩行させる事が出来る事を示し た. 